EVIDENCE BASED PUBLIC HEALTH POLICY AND PRACTICE

\title{
Work related and non-work related stress in relation to low leisure time physical activity in a Swedish population
}

\author{
Karl Magnus Wemme, Maria Rosvall
}

J Epidemiol Community Health 2005;59:377-379. doi: 10.1136/jech.2004.031526

$\mathrm{P}$

hysical activity is regarded as an important component of a healthy lifestyle. Several social and environmental factors have systematically emerged as barriers to low leisure time physical activity (LTPA), for example, lack of money, low social support due to lack of supportive family or friends, and living in high crime rate areas. Low LTPA has been found to be strongly associated with low socioeconomic status groups where psychosocial stressors have been suggested to play a mediating part. $^{1{ }^{2}}$

The overall aim of this study was to investigate the association between work and non-work related stressors, respectively, in relation to low LTPA in a general population sample. Our main hypothesis was that psychosocial stressors would act as barriers to physical activity thus generating sedentary behaviour as measured by LTPA.

\section{METHODS}

The Scania health survey was conducted during the period of November 1999 through April 2000. After excluding refusals, non-contacts, and other non-responding groups, the final sample consisted of 13715 persons, making the response rate $59 \%$ of the sample size. A self administered questionnaire provided information regarding health related behaviours, sociodemographic characteristic, and psychosocial factors. Our analysis was restricted to currently employed people (52\% of the sample population) yielding a study population of 7169 subjects ( 3877 men and 3292 women). Odds ratios for low LTPA in relation to psychosocial variables were calculated using two logistic regression models, model one with adjustment for age, model two with adjustment for age, socioeconomic status, marital/cohabiting status, ethnicity, and physically active work.

\section{Work related stressors}

We used the instrument developed by Karasek and Theorell to assess psychosocial environment at work and to measure psychological job demands and job decision latitude. ${ }^{3}$ Wish to change profession describes whether a person is experiencing enclosure in the work situation (yes or no). Working hours per week was defined either as "regular" or "overtime", and termed often if it was a monthly occurrence. Lack of influence on overtime work was a simple yes or no question.

\section{Non-work related stressors}

Social participation describes how actively the person takes part in the activities of formal and informal groups in society. A high daily stress level was defined as often being daily stressed. Economic stress was estimated as people who cannot pay their bills on a regular basis-that is, have had difficulties once every other month for the past year.

Social trust reflects the person's sense of security in the society they live in and to what extent they trust one another. Social anchorage in neighbourhood describes to what extent the person belongs to and is anchored within formal and informal groups. Emotional support is equal to having a supportive environment through family and friends. Instrumental support is equal to having access to help with practical matters.

The level of leisure time physical activity was measured by asking respondents "how much do you move and exert yourself physically on leisure time, domestic work excluded", and was assessed by a multiple choice question with four alternatives (low, moderate, regular, and vigorous) The outcome measure Low leisure time physical activity behaviour was categorised as "spending most of the time reading, doing

Table 1 Prevalences, age adjusted odds ratios (OR), and 95\% confidence intervals (Cl) of low leisure time physical activity in relation to educational level and socioeconomic status. The Scania health survey 2000

\begin{tabular}{|c|c|c|c|c|c|c|}
\hline \multirow[b]{3}{*}{ Total } & \multicolumn{3}{|l|}{ Men } & \multicolumn{3}{|l|}{ Women } \\
\hline & \multirow{2}{*}{$\begin{array}{l}\begin{array}{l}\text { Number } \\
\text { (total) }\end{array} \\
3877\end{array}$} & \multirow[b]{2}{*}{ OR } & \multirow[b]{2}{*}{$95 \% \mathrm{Cl}$} & \multirow{2}{*}{$\begin{array}{l}\begin{array}{l}\text { Number } \\
\text { (total) }\end{array} \\
3292\end{array}$} & \multirow[b]{2}{*}{ OR } & \multirow[b]{2}{*}{$95 \% \mathrm{Cl}$} \\
\hline & & & & & & \\
\hline \multicolumn{7}{|l|}{ Education level } \\
\hline University & 1554 & 1.0 & $-^{*}$ & 1537 & 1.0 & $-^{*}$ \\
\hline Secondary school & 1385 & 1.5 & (1.2 to 1.9$)$ & 1147 & 1.5 & (1.2 to 1.9 ) \\
\hline Compulsory school & 890 & 1.9 & (1.4 to 2.4 ) & 608 & 1.8 & (1.5 to 2.3 ) \\
\hline Socioeconomic status & & & & & & \\
\hline High level non-manual & 587 & 1.0 & $-^{*}$ & 519 & 1.0 & $-^{*}$ \\
\hline Middle level non-manual & 725 & 1.2 & (0.9 to 1.8$)$ & 569 & 1.0 & $(0.7$ to 1.5$)$ \\
\hline Low level non-manual & 371 & 1.5 & (1.1 to 2.2$)$ & 631 & 1.7 & (1.1 to 2.5 ) \\
\hline Skilled manual worker & 547 & 1.4 & (1.1 to 2.0$)$ & 800 & 1.1 & (0.7 to 1.7 ) \\
\hline Unskilled manual worker & 700 & 1.8 & (1.3 to 2.4 ) & 376 & 2.1 & (1.4 to 3.1$)$ \\
\hline Self employed and farmers & 440 & 1.8 & (1.3 to 2.5$)$ & 144 & 1.3 & (0.8 to 2.4 ) \\
\hline
\end{tabular}


Table 2 Prevalences, age adjusted and multivariate odds ratios (OR), and 95\% confidence intervals $(\mathrm{Cl})$ of low leisure time physical activity in relation to psychosocial variables. The Scania health survey 2000

\begin{tabular}{|c|c|c|c|c|c|}
\hline & $\begin{array}{l}\text { Number } \\
\text { (total) }\end{array}$ & $\begin{array}{l}\text { Model } 1 \\
\text { OR* }^{*}\end{array}$ & $95 \% \mathrm{Cl}$ & Model 2 OR† & $95 \% \mathrm{Cl}$ \\
\hline \multicolumn{6}{|l|}{ Men } \\
\hline Mean (SE) age & \multicolumn{5}{|c|}{$41.99(0.19)$} \\
\hline Total & \multirow{2}{*}{\multicolumn{5}{|c|}{3877}} \\
\hline \multicolumn{2}{|l|}{ Work related stress } & & & & \\
\hline Wish to change profession & 912 & 1.4 & (1.2 to 1.8$)$ & 1.4 & (1.1 to 1.7$)$ \\
\hline \multicolumn{6}{|l|}{ Overtime: } \\
\hline Offen & 970 & 1.3 & (1.1 to 1.7$)$ & 1.3 & (1.1 to 1.6$)$ \\
\hline $\begin{array}{l}\text { Lack of influence on } \\
\text { overtime work }\end{array}$ & 835 & 1.3 & (1.01 to 1.6$)$ & 1.3 & $(1.0$ to 1.7$)$ \\
\hline \multicolumn{6}{|l|}{ Job strain categories: } \\
\hline Relaxed & 542 & 1.0 & $-\ddagger$ & 1.0 & $-\ddagger$ \\
\hline Active & 797 & 1.0 & $(0.7$ to 1.3$)$ & 1.3 & $(0.9$ to 1.9$)$ \\
\hline Passive & 657 & 1.3 & $(1.0$ to 1.7$)$ & 1.7 & (1.2 to 2.4$)$ \\
\hline Job strain & 521 & 1.5 & $(1.1$ to 2.0$)$ & 1.4 & $(1.0$ to 2.0$)$ \\
\hline \multicolumn{6}{|l|}{ Non-work related stress } \\
\hline High daily stress level & 778 & 1.8 & (1.5 to 2.2$)$ & 2.0 & (1.6 to 2.4$)$ \\
\hline Economic distress & 257 & 2.3 & (1.7 to 3.0$)$ & 2.2 & (1.6 to 3.1$)$ \\
\hline Low social participation & 880 & 2.7 & (2.2 to 3.2$)$ & 2.3 & (1.9 to 2.9 ) \\
\hline Low social trust & 1486 & 1.8 & (1.5 to 2.1$)$ & 1.7 & (1.4 to 2.1$)$ \\
\hline $\begin{array}{l}\text { Low social anchorage in } \\
\text { neighbourhood }\end{array}$ & 1028 & 1.4 & (1.2 to 1.7$)$ & 1.3 & $(1.1$ to 1.6$)$ \\
\hline \multicolumn{6}{|l|}{ Lack of social support: } \\
\hline Emotional & 1463 & 1.4 & (1.2 to 1.7$)$ & 1.3 & $(1.1$ to 1.6$)$ \\
\hline Instrumental & 1049 & 1.5 & $(1.3$ to 1.8$)$ & 1.3 & (1.1 to 1.6$)$ \\
\hline Sedentary behaviour & 661 & & & & \\
\hline \multicolumn{6}{|l|}{ Women } \\
\hline Mean (SE) age & \multicolumn{5}{|l|}{$42.15(0.2)$} \\
\hline Total & \multicolumn{5}{|l|}{3292} \\
\hline \multicolumn{6}{|l|}{ Work related stress } \\
\hline Wish to change profession & 841 & 1.3 & (1.1 to 1.7$)$ & 1.3 & (1.03 to 1.8$)$ \\
\hline \multicolumn{6}{|l|}{ Overtime: } \\
\hline Often & 587 & 0.9 & (0.7 to 1.2$)$ & 0.9 & (0.6 to 1.2$)$ \\
\hline $\begin{array}{l}\text { Lack of influence on } \\
\text { overtime work }\end{array}$ & 679 & 1.1 & $(0.9$ to 1.5$)$ & 1.1 & $(0.8$ to 1.5$)$ \\
\hline \multicolumn{6}{|l|}{ Job strain categories: } \\
\hline Relaxed & 318 & 1.0 & $-\ddagger$ & 1.0 & $-\ddagger$ \\
\hline Active & 491 & 0.7 & (0.5 to 1.1$)$ & 0.8 & $(0.5$ to 1.2$)$ \\
\hline Passive & 591 & 0.8 & $(0.5$ to 1.1$)$ & 0.8 & (0.5 to 1.2$)$ \\
\hline Job strain & 534 & 1.2 & $(0.8$ to 1.6$)$ & 1.1 & $(0.8$ to 1.6$)$ \\
\hline \multicolumn{6}{|l|}{ Non-work related stress } \\
\hline High daily stress level & 959 & 1.2 & (1.0 to 1.5$)$ & 1.1 & (0.9 to 1.4$)$ \\
\hline Economic distress & 281 & 1.6 & $(1.2$ to 2.2$)$ & 1.6 & (1.1 to 2.2 ) \\
\hline Low social participation & 639 & 2.7 & $(2.2$ to 3.4$)$ & 2.8 & $(2.2$ to 3.6$)$ \\
\hline Low social trust & 1412 & 1.2 & (1.01 to 1.5$)$ & 1.2 & (1.0 to 1.5$)$ \\
\hline Low social anchorage in & 765 & 2.2 & $(1.8$ to 2.8$)$ & 2.2 & (1.7 to 2.7$)$ \\
\hline \multicolumn{5}{|l|}{ Lack of social support: } & \\
\hline Emotional & 924 & 1.9 & (1.6 to 2.3$)$ & 1.9 & (1.4 to 2.3 ) \\
\hline Instrumental & 641 & 1.9 & $(1.5$ to 2.4$)$ & 1.8 & (1.4 to 2.4 ) \\
\hline Sedentary behaviour & 462 & & & & \\
\hline
\end{tabular}

needlework, watching television, going to the cinema, or doing other non-physical activities". This sedentary group does not accumulate 30 minutes or more of moderate LTPA every day of the week and are therefore to be considered as a risk group as suggested in an important published public health message from 1995. ${ }^{5}$ The four category item has been compared with more detailed measures of LTPA where the category of low physical activity has been known to have high validity. ${ }^{\circ}$

\section{RESULTS}

Low education and low occupational status was strongly associated with low LTPA (table 1). Overall, psychosocial factors not related to work showed strong associations with low LTPA, where somewhat different patterns of association could be seen in men and women as shown in table 2 . Work related stressors generally showed weak associations with low LTPA in women, while non-work related psychosocial stressors showed stronger associations. However, male subjects were found to be more likely to have low LTPA if exposed to overtime work, "passive" work situation, "job strain", and "a wish to change profession". Adjustment for confounders (socioeconomic status, marital/cohabiting status, ethnicity, and physically active work) did not change the result in a major way (table 2 )

\section{DISCUSSION}

Regarding the measures of non-work related stress there were overall significant associations with low LTPA. For both men and women low social participation was strongly associated with low LTPA. This is consistent with the results from other studies that support the notion that social participation is an important determinant for health related behaviours. ${ }^{1}$ Furthermore, other studies have reported that 
lack of money and lack of time are important barriers for physical activity. ${ }^{78}$ Economic distress and a high daily stress level seemed to be more important as potential barriers for men than for women.

Long term illness, measured as being ill, or disabled for a long time, can restrict the possibilities and willingness to exercise and is a potential confounder. However, when adjusted for age and long term illness the results remained nearly unchanged.

Pearson's two tailed correlation test was performed to investigate the relations between the concepts of work and non-work related stress. "A high daily stress level" was correlated with many work related stressors, for example, "Wish to change profession" $(0.132 \mathrm{p}<0.001)$, "Often work overtime" $(0.157 \mathrm{p}<0.001)$, and "Job strain model" $(0.263$ $\mathrm{p}<0.001$ ), showing that this variable stretches over both concepts.

Stressful life situations are likely to affect a person's wellbeing and the health related behaviours. For example, having a very good marital relationship improves psychological wellbeing and in reverse a low job support worsens it. ${ }^{9}$ That is to say that a bad domestic situation (for example, low support) may affect working life negatively and poor working conditions (for example, job strain) may affect domestic life. Although the concepts of work related and non-work related stress are likely to have an impact on each other, studies have shown an independent effect in both directions. ${ }^{910}$ Finally, there is a suggested positive "spill-over" effect of a positive job experience into leisure time activities leading to healthier behaviour. A negative job experience is less likely to be counterbalanced in leisure time by healthy activities such as physical activity. ${ }^{3}$ Poor working conditions seemed to affect men somewhat more negatively than women, in relation to low LTPA. However, the result from this should be confirmed by a prospective study, because of the problem with causal direction in cross sectional studies.

\section{Authors' affiliations}

K M Wemme, Department of Social and Preventive Medicine, Malmö University Hospital, Malmö, Sweden

M Rosvall, Department of Community Medicine, Lund University, Malmö University Hospital

Funding: financial support from The County Council of Scania made this study possible.

Conflicts of interest: none declared.

Correspondence to: Dr K M Wemme, Department of Social and Preventive Medicine, Malmö University Hospital, SE-205 02 Malmö, Sweden; magnus.wemme@smi.mas.lu.se

Accepted for publication 23 November 2004

\section{REFERENCES}

1 Lindström M. Social participation, social capital and socioeconomic differences in health-related behaviours. An epidemiological study. (Dissertation). Malmö: Lund University, Department of Community Medicine, 2000.

2 Vilhiamsson R, Thorlindsson T. Factors related to physical activity: a study of adolescents. Soc Sci Med 1998;47:665-75.

3 Karasek P, Theorell T. Healthy work. Stress, productivity and the reconstruction of working life. New York: Basic Books, 1990.

4 Karasek RA. Job demands, job decision latitude, and mental strain. Implications for job redesign. Adm Sci Q 1979;24:285

5 Pate RR, Pratt M, Blair SN, et al. Physical activity and public health. JAMA 1995:273:402-7.

6 Lindström M, Moghadassi M, Merlo J. Social capital and leisure time physical activity: a population based multilevel analysis in Malmö, Sweden. J Epidemiol Community Health 2003;57:23-8.

7 Ziebland S, Thorogood M, Yudkin P, et al. Lack of willpower or lack of wherewithal? "Internal" and "external" barriers to changing diet and exercise in three-year follow-up participants in a health check. Soc Sci Med 1997;46:461-5.

8 Chinn DJ, White M, Harland J, et al. Barriers to physical activity and socioeconomic position: implications for health promotion. J Epidemiol Community Health 1999:53:191-2.

9 Escriba-Aguir V, Tenias-Burillo JM. Psychosocial well-being among hospital personnel: The role of family demands and psychosocial work environment. Int Arch Occup Environ Health 2004;77:401-8.

10 Cheng Y, Kawachi I, Coakley E, et al. Association between psychosocial work characteristics and health functions in American women: prospective study. BMJ 2000;320:1432-6. 